\title{
Composição centesimal e valor protéico de levedura residual da fermentação etanólica e de seus derivados
}

\section{Centesimal composition and protein nutritive value of from ethanol fermentation and of yeast derivatives}

Eunice Akemi YAMADA ${ }^{1}$

Izabela Dutra ALVIM ${ }^{1}$

Marjorie Carelli Costa SANTUCCI

Valdemiro Carlos SGARBIERI ${ }^{1}$

\section{RE S U M O}

Este trabalho teve por objetivo promover a autólise e o fracionamento da levedura (Saccharomyces sp.) para produção de autolisado e extrato, bem como para produção de concentrado protéico fosforilado, a partir da levedura residual das destilarias de álcool etílico. Foram estudados a composição centesimal, o perfil de aminoácidos essenciais e o valor protéico dos três derivados comparativamente à levedura íntegra não processada. Proteína e carboidrato (fibra alimentar) foram os principais componentes da levedura íntegra e do autolisado. No extrato e no concentrado protéico predominaram proteína e minerais (cinzas). O autolisado e a levedura íntegra apresentaram os melhores índices de aminoácidos essenciais, seguidos pelo concentrado protéico e pelo extrato. A digestibilidade da proteína variou de $68 \%$ para a levedura íntegra a $91 \%$ para o extrato. Os índices de quociente de utilização líquida da proteína variaram de 2,1 para a levedura íntegra a 4,3 para a caseína (referência). Não houve diferença estatística no quociente de utilização líquida da proteína entre o autolisado $(4,1)$, o extrato $(3,9)$ e o concentrado protéico $(4,2)$. O concentrado protéico promoveu o maior crescimento no período (21 dias), seguido do extrato e o autolisado. As células íntegras apresentaram a menor capacidade para promover crescimento em rato.

Termos de indexação: Saccharomyces, células íntegras, autolisado, extrato, concentrado protéico, proteínas de Saccharomyces cerevisiae, fermentação.

\section{A B S T R A C T}

The objective of this work was to promote the autolysis and the fractionation of the yeast (Saccharomyces sp.) for the production of autolysate and extract, as well as phosphorylated protein concentrate, from ethanol

\footnotetext{
1 Instituto de Tecnologia de Alimentos, Centro de Química de Alimentos e Nutrição Aplicada. Av. Brasil, 2880, 13073-001, Campinas, SP, Brasil. Correspondência para/Correspondence to: V.C.SGARBIERI.
} 
distillery yeast. Comparative studies of centesimal composition, essential amino acid profiles and protein nutritive value were performed for the unprocessed integral cells, and for autolysate, extract and phosphorylated protein concentrate. Protein and carbohydrate (dietary fiber) were the main components for the integral cells and autolysate. For the extract and the protein concentrate the main components were protein and minerals (ashes). The autolysate and the integral cells presented the highest essential amino acid indexes, followed by the protein concentrate and the extract. Protein digestibility ranged from 68\% (integral cells) to 91\% (extract). Net protein ratio ranged from 2.1 (integral cells) to 4.3 (casein-reference). There was no statistical difference in Net protein ratio among autolysate, extract and protein concentrate (3.9 to 4.2). The protein concentrate promoted the highest growth in the period (21 days), followed by the extract and the autolysate. The integral cells showed the lowest capacity to promote rat growth.

Index terms: Saccharomyces, integral cells, autolysate, extract, protein concentrate, Saccharomyces cerevisiae proteins, fermentation.

\section{N T R O D U Ç Ã O}

A levedura Saccharomyces cerevisiae é utilizada na indústria de alimentos e bebidas em diversas formas ${ }^{1-3}$.

Em forma ativa, a Saccharomyces é utilizada na indústria de panificação ${ }^{4}$, na fermentação alcoólica ${ }^{5}$ e em outros processos fermentativos. Na forma inativa, essa levedura tem sido muito usada na alimentação animal ${ }^{6}$, como fonte de proteína e outros nutrientes, e em alimentação humana, principalmente na forma de derivados, como complemento nutritivo, aromatizante e realçador de sabor ${ }^{3,4}$.

A Saccharomyces cerevisiae utilizada como agente de fermentação (pães, cerveja, produção de álcool etílico) é produzida por processos bem controlados, em fermentadores, com elevado grau de pureza.

Nas destilarias de álcool (etanol) e nas cervejarias são gerados excedentes de células de levedura que, inativadas termicamente ou não, poderão ser usadas diretamente (células íntegras de levedura) ou ser processadas para obtenção de vários derivados. As células íntegras são usadas principalmente na alimentação animal, enquanto certos derivados como o autolisado (AT) e o extrato de levedura (Ex) vêm sendo utilizados de longa data na formulação de produtos para humanos, como complemento nutritivo e flavorizante.
Além de apresentar elevado teor em proteína (30\% a $70 \%$ ), os produtos de levedura são ricos em vitaminas do complexo $B\left(B_{1}, B_{2}, B_{6}\right.$, ácido pantotênico, niacina, ácido fólico e biotina), em minerais, em macro e microelementos, particularmente selênio e fibra dietética, representados por carboidratos da parede celular, principalmente mananas e glicanas ${ }^{3}$.

Com o objetivo de melhor avaliar o potencial alimentício da levedura produzida como subproduto (resíduo) da indústria de cervejas e de etanol, uma série de pesquisas têm sido realizadas $^{7-10}$.

Neste trabalho são relatados resultados sobre a composição e o valor nutritivo da proteína de células íntegras e de alguns derivados obtidos a partir da levedura residual da fermentação alcoólica.

MATERIALE MÉTODOS

O material de estudo foi coletado em destilaria de álcool etílico após seu uso na fermentação alcoólica, na forma de uma suspensão, com $20 \%$ (p/v) de células, comumente designada como "leite" de levedura. Esse material contém ainda elevada concentração de álcool e de outros componentes do mosto de fermentação, como contaminantes. Esses contaminantes são eliminados, em boa parte, por lavagens com água 
e separação por centrifugação, antes de prosseguir com o processamento.

Os processos aplicados para obtenção da biomassa de levedura e de seus derivados (autolisado e extrato) foram essencialmente os descritos para levedura residual de cervejaria7, exceto pelo tratamento com álcali para eliminar amargor, que não se mostrou necessário para levedura de fermentação etanólica.
A preparação do concentrado protéico fosforilado de levedura foi feita de acordo com a Figura 1.

Após rompimento das paredes celulares em um moinho (DynoMill), a suspensão foi centrifugada para separar a fração solúvel (sobrenadante). Ao sobrenadante foi adicionado trimetafosfato de sódio (TMFS) a 4\% (p/p), sendo mantido sob agitação durante $3 \mathrm{~h}$ a $35^{\circ} \mathrm{C}$. Após

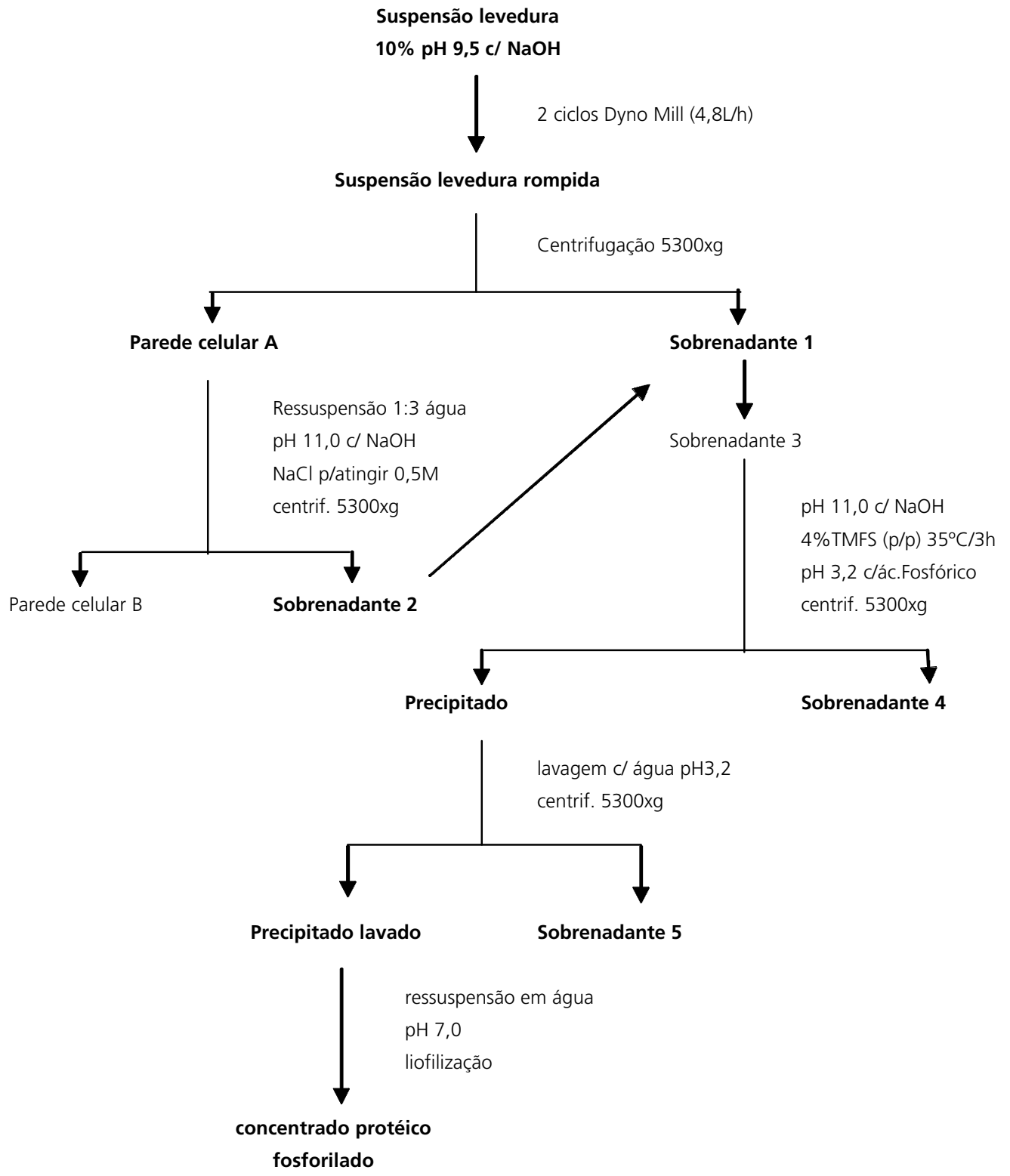

Figura 1. Fluxograma de obtenção do concentrado proteíco fosforilado. 
3h, o pH foi baixado a 3,2 com ácido fosfórico a $85 \%$ e o precipitado formado foi separado por centrifugação. Após lavagem com água destilada acidificada, o precipitado lavado foi ressuspenso em água, ajustado para o pH 7,0 com solução de $\mathrm{NaOH}$, seguindo-se a desidratação por liofilização. Desta forma, obteve-se o Concentrado Protéico Fosforilado (CPF).

Umidade, cinzas e proteína bruta $(\mathrm{N} \times 5,8)$ foram determinadas basicamente segundo a Association of Official Agricultural Chemists ${ }^{11}$. Lipídios totais foram determinados pelo método de Bligh \& Dyer (1959)12. Fibra alimentar, solúvel e insolúvel foi identificada pela técnica de Asp et al. (1983) ${ }^{13}$. Obteve-se o ácido ribonucléico (RNA) seguindo-se o procedimento de Herbert et al. (1971) 14 .

A composição em aminoácidos foi determinada em aparelho HPLC (Dionex Dx-300), com separação em colunas de troca catiônica e reação pós-coluna com ninidrina. As amostras foram previamente submetidas à hidrólise ácida $\left(\mathrm{HCl} 6 \mathrm{~N}, 105^{\circ} \mathrm{C}, 22 \mathrm{~h}\right)$, seguindo-se eliminação do ácido em rotavapor, sob vácuo, e redissolução dos aminoácidos em tampão apropriado. A quantificação de cada aminoácido foi feita com base em mistura padrão de aminoácidos fornecida pela Pierce Rockford, Illinois, USA (Aminoacid Standard $H^{\circ} N^{\circ}$ 20088). A determinação do triptofano foi realizada segundo metodologia descrita por Spies (1967) ${ }^{15}$.

\section{Ensaios com ratos}

Para a avaliação nutricional foram utilizados ratos machos da linhagem Wistar, recém-desmamados (21 dias), livres de patógenos específicos (SPF), adquiridos do Centro de Animais de Laboratório (CEMIB) da Universidade Estadual de Campinas.

Foram utilizados 48 ratos distribuídos em seis grupos (8 ratos em cada um), por meio de um planejamento inteiramente casualizado. Os animais foram previamente selecionados, de tal forma que a variação de peso não fosse superior a $10 \%$ da média. As condições do laboratório de ensaio foram temperatura $22 \pm 2^{\circ} \mathrm{C}$, com períodos alternados de claro-escuro de $12 \mathrm{~h}$. A duração total do ensaio foi de três semanas (21 dias); durante todo o período os animais foram mantidos em gaiolas individuais e tiveram livre acesso à dieta e à água.

As dietas foram preparadas de acordo com recomendações do American Institute of Nutrition ${ }^{16}$, exceto pela concentração de proteína (10\% ao invés de $17 \%$ ) e pela substituição da proteína por carboidrato na dieta aprotéica. Ao todo foram preparadas seis dietas, a saber: isenta de proteína (AP); 10\% de proteína de células íntegras de levedura (LI); $10 \%$ de Autolisado de Levedura (AT); 10\% de Extrato de Levedura (Ex); $10 \%$ de concentrado de levedura fosforilado (CPF); 10\% de caseína (controle).

Na primeira semana, registraram-se apenas o consumo de dieta e o ganho de peso dos animais. Na segunda semana, além de efetuar este registro, foram coletadas as fezes. Na terceira semana, registraram-se apenas consumo de dieta e ganho de peso.

Os índices nutricionais determinados experimentalmente foram: a) digestibilidade verdadeira da proteína, calculada pelo quociente entre o nitrogênio absorvido e o nitrogênio ingerido, já descontado no cálculo da absorção o N das fezes do grupo em dieta aprotéica (Dv = NA/NI x 100); b) quociente de utilização líquida da proteína (NPR), obtido pela expressão: NPR = ganho de peso do grupo em dieta experimental + perda de peso do grupo em dieta aprotéica/ingestão de proteína do grupo em dieta experimental.

Foram ainda calculados o escore de aminoácidos essenciais (EAE \%), com base no aminoácido mais limitante, tendo como referência o padrão teórico da Food and Agriculture Organization/World Health Organization (FAOMHO) de $1989^{17}$ para crianças de 2 a 5 anos de idade. O produto do EAE pela Dv forneceu o PDCAAS (Digestibilidade corrigida pelo escore 
de aminoácidos essenciais), de acordo com Henley \& Kuster (1994) ${ }^{18}$.

\section{RESULTADOSE DISCUSS ÃO}

Determinou-se a composição centesimal das células de levedura íntegra (LI), do autolisado (AT), do extrato (Ex) e do concentrado protéico fosforilado (CPF) de levedura, oriunda de destilaria de álcool etílico (Tabela 1).

De acordo com a análise quantitativa dos dados referentes à composição centesimal, os componentes mais importantes da levedura proveniente de destilarias de álcool são a proteína, a fibra, as cinzas e o ácido ribonucléico. Comparadas com as células de levedura íntegra, provenientes de cervejaria, as de destilaria de álcool apresentaram teor mais baixo de proteína e de lipídios totais e teores mais elevados de fibra alimentar total, de cinzas e de ácido ribonucléico ${ }^{8,9}$.

A composição não se modificou muito quando as células íntegras (LI) foram submetidas ao processo de autólise para obtenção do autolisado (AT). Isso se explica pelo fato de que o autolisado contém, teoricamente, todos os componentes da célula. Contudo, o extrato (Ex) e o concentrado protéico apresentaram composição bastante diferente das células íntegras como resultado do processo de fracionamento.

O Ex apresentou elevado teor de proteína $(50,7 \%)$, de cinzas $(11,7 \%)$ e de componentes não determinados (25,6\%). No Ex, os componentes não determinados são representados particularmente pela maltodextrina, acrescentada ao extrato na proporção de $25 \%$ p/p dos sólidos totais, para facilitar sua secagem e conservação. A fração apresentou baixo teor de fibra (solúvel) e ausência de fibra insolúvel. O elevado teor de cinzas do Ex é, em grande parte, proveniente do cloreto de sódio adicionado como agente plasmolisante no processo de autólise.

No concentrado protéico, o componente mais importante foi a proteína $(62,4 \%)$, seguido de cinzas (13,0\%), do ácido ribonucléico (9,8\%) e de lipídios totais (8,5\%). A elevada concentração de cinzas deve-se, provavelmente, ao fosfato acrescentado no processo de fosforilação da proteína pelo trimetafosfato de sódio (TMFS). Tanto o fosfato como os lipídios são co-precipitados ligados às proteínas, pois foram eliminados pelo processo de lavagem que se seguiu à precipitação.

A co-precipitação de fosfato, lipídios e RNA aumenta com o abaixamento do $\mathrm{pH}$ de precipitação da proteína, que neste trabalho foi 3,2. Conforme esses contaminantes aumentam no concentrado protéico, o teor de proteína diminui.

Em levedura de cervejaria, quando o pH de precipitação da proteína esteve na faixa 3,8 a $4,2^{8,9}$, a concentração de proteína no concentrado final foi de $74 \%$ para proteína fosforilada e $76 \%$ para a proteína extraída com perclorato de sódio; o conteúdo de RNA caiu para a faixa de 2,2 a 3,7. À medida que aumenta o pH de precipitação

Tabela 1. Composição centesimal da levedura íntegra e de derivados de levedura de destilaria de álcool.

\begin{tabular}{lcccc}
\hline Componente (\% b.s.) & Levedura íntegra & Autolisado & Extrado & Concentrado Protéico Fosforilado \\
\hline Proteína (Nx5,8) & 39,6 & 40,4 & 50,7 & 62,4 \\
Fibra alimentar & & & & 6,2 \\
$\quad$ total & 31,4 & 31,2 & 3,3 & $\mathrm{ND}$ \\
$\quad$ solúvel & 30,3 & 30,4 & 3,3 & $\mathrm{ND}$ \\
$\quad$ insolúvel & 1,1 & 1,0 & 0,0 & 13,0 \\
Cinzas & 4,6 & 6,2 & 11,7 & 8,5 \\
Lipídios totais & 0,5 & 1,2 & 0,4 & 9,8 \\
Ácido ribonucléico & 9,0 & 5,6 & 8,3 & 0,1 \\
Não determinado & 14,9 & 15,4 & 25,6 & \\
\hline
\end{tabular}


da proteína, o rendimento em concentrado diminui bastante.

Era de interesse, neste trabalho, obter o máximo rendimento em concentrado protéico, ainda que fosse com a diminuição na concentração final de proteína e com uma pequena elevação no teor de RNA.

Foram caracterizados os perfis de aminoácidos essenciais das células da levedura íntegra, do autolisado, do extrato e do concentrado protéico fosforilado de levedura da fermentação alcoólica (Tabela 2).

Observou-se uma pequena deficiência de leucina (Leu) para a levedura íntegra (LI) e para o extrato de levedura (Ex), enquanto o autolisado de levedura (AT) satisfez inteiramente as exigências em aminoácidos essenciais do padrão teórico da FAOMHO, para crianças de 2 a 5 anos de idade.
Os resultados do escore de aminoácidos essenciais para a proteína de levedura da fermentação alcoólica foram semelhantes aos determinados por Caballero-Córdoba \& Sgarbieri $(2000)^{8}$ para a levedura de cervejaria, cujos valores foram $98,1 \%$ e $87,2 \%$ para as células íntegras e concentrado protéico, respectivamente.

Foram levantados os dados de digestibilidade verdadeira da proteína das células íntegras de levedura e de seus derivados e foram calculados os PDCAAS, com base no EAE e Dv (Tabela 3).

A digestibilidade da proteína das células de levedura íntegra foi bem inferior à de seus derivados. Esse fator tem um significado nutricional bastante importante e tem sido enfatizado por vários pesquisadores ${ }^{20,21}$. A baixa digestibilidade protéica nas células íntegras é atribuída à resistência da parede celular à ação das enzimas digestivas, principalmente em animais monogástricos.

Tabela 2. Aminoácidos essenciais e escore de aminoácidos essenciais de levedura íntegra de destilaria de álcool e seus derivados.

\begin{tabular}{lccccc}
\hline Aminoácido (g/100gprot.) & Levedura íntegra & Autolisado & Extrado & Concentrado Protéico Fosforilado & FAOMHO(1) $^{(1)}$ \\
\hline Treonina & 4,7 & 5,2 & 3,7 & 5,0 & 3,4 \\
Metionina + cistina & 2,4 & 2,7 & 2,3 & $2,3^{*}$ & 2,5 \\
Valina & 4,8 & 5,4 & 4,6 & 6,1 & 3,5 \\
Leucina & $6,0^{*}$ & 6,7 & $5,6^{*}$ & 8,5 & 6,6 \\
Isoleucina & 4,2 & 4,7 & 3,9 & 9,2 & 2,8 \\
Fenilalanina + tirosina & 6,5 & 7,4 & 6,4 & 9,3 & 5,8 \\
Lisina & 7,8 & 9,0 & 7,0 & 2,4 & 5,8 \\
Histidina & 4,2 & 2,7 & 2,4 & 1,8 & 1,9 \\
Triptofano & 1,2 & 1,5 & 1,1 & 0,92 Met+(Cys) & \\
\hline EAE & 0,91 (Leu) & $>1,0$ & 0,85 (Leu) & & 1,1 \\
\hline
\end{tabular}

(1) FAOMHO (1989) ${ }^{17}$; (*) Aminoácido mais limitante

Tabela 3. Digestibilidade verdadeira e PDCCAAS para proteína da levedura íntegra de destilaria de álcool e de seus derivados.

\begin{tabular}{lcc}
\hline Fonte protéica & Digestibilidade verdadeira & PDCAAS(\%) \\
\hline Levedura íntegra & $68,0 \mathrm{c}$ & 61,9 \\
Autolisado & $76,6 \mathrm{~b}$ & 76,6 \\
Extrato & $91,0 \mathrm{a}$ & 77,4 \\
Concentrado protéico fosforilado & $89,9 \mathrm{a}$ & 82,7 \\
Caseína comercial (padrão) & $93,5 \mathrm{a}$ & $82,3^{(1)}$ \\
\hline
\end{tabular}

(1)EAE para caseína 0,88 (Met+Cys). Fonte: Zinsly et al. (2001)22.

Letras diferentes (colunas) expressam diferenças estatísticas $(p<0,05)$. 
Se comparada com as células íntegras de cervejaria ${ }^{9}$, a digestibilidade da proteína dessas células ( $83 \%$ ) foi bem superior à encontrada neste estudo para as células da levedura proveniente de destilarias de álcool etílico (68\%). A grande diferença de capacidade das enzimas digestivas do rato na digestão da proteína da mesma levedura, porém submetida a estresses diferentes em virtude de diferentes processos, leva a crer que a parede celular da levedura de destilaria de álcool torna-se mais espessa e mais resistente às enzimas digestivas, dificultando a proteólise enzimática nas células íntegras, embora fatores como diferentes cepas e metabolismo possam ter alguma influência. Daí a importância do rompimento da parede celular com vistas à melhoria da digestibilidade e da utilização da proteína neste tipo de levedura.

No autolisado há um rompimento parcial das paredes celulares, provocando uma melhoria significativa da digestibilidade protéica. Entretanto, os valores mais elevados foram obtidos no extrato e no concentrado protéico, pelo fato de não haver células íntegras nessas preparações e as proteínas estarem totalmente disponíveis à ação enzimática. No Ex e no CPF, a digestibilidade da proteína não diferiu significativamente da caseína.

O PDCAAS reflete o balanço de aminoácidos essenciais e a digestibilidade verdadeira da proteína. Os valores mais altos foram encontrados na caseína e no CPF, que apresentaram os melhores perfis de aminoácidos essenciais e ao mesmo tempo boa digestibilidade.
O autolisado (AT), apesar do excelente perfil aminoacídico, teve sua digestibilidade afetada pela presença de células intactas e componentes da parede celular registrando, portanto, PDCAAS relativamente baixo. O extrato (Ex), embora tenha apresentado a mais alta digestibilidade, teve seu PDCAAS prejudicado pelo menor $\operatorname{EAE}(0,85)$.

Foram calculados o consumo de dieta e de proteína, o ganho de peso corporal no período de 21 dias e os valores de NPR (quociente de utilização líquida da proteína) (Tabela 4).

A análise cuidadosa dos dados acima mostra alguns aspectos interessantes. Os ratos que receberam células íntegras (LI) como fonte de proteína apresentaram o mais baixo consumo de dieta e de proteína e, conseqüentemente, o mais baixo ganho de peso e valor de NPR significativamente inferior aos demais tratamentos $(p<0,05)$.

Se comparados com a levedura de cervejaria ${ }^{9}$, os resultados relatados neste trabalho para a levedura íntegra de destilaria de álcool são diferentes.

Os valores de NPR para a levedura de cervejaria variaram entre 3,6 e 3,8 para LI, AT e $E x$, não diferindo estatisticamente entre si $(p>0,05)$, enquanto na levedura de destilaria o NPR para LI foi bem inferior $(2,1)$. No entanto, os valores de NPR para AT e Ex foram equivalentes para as leveduras de cervejaria e de destilaria.

Tabela 4. Consumo de dieta, ganho de peso e NPR de ratos alimentados com dietas contendo $10 \%$ de proteína.

\begin{tabular}{lcccc}
\hline Fonte protéica & Consumo dieta $(\mathrm{g})$ & Consumo proteína $(\mathrm{g})$ & Ganho de peso $(\mathrm{g})$ & NPR \\
\hline Levedura íntegra & $183,4 \pm 33,2 \mathrm{c}$ & $18,3 \pm 3,3 \mathrm{c}$ & $25,4 \pm 6,5 \mathrm{c}$ & $2,1 \mathrm{~b}$ \\
Autolisado & $265,8 \pm 25,3 \mathrm{~b}$ & $27,7 \pm 2,6 \mathrm{~b}$ & $98,4 \pm 8,6 \mathrm{~b}$ & $4,1 \mathrm{a}$ \\
Extrato & $313,9 \pm 32,0 \mathrm{a}$ & $33,6 \pm 3,4 \mathrm{a}$ & $114,3 \pm 12,3 \mathrm{a}$ & $3,9 \mathrm{a}$ \\
Concentrado protéico fosforilado & $340,2 \pm 39,6 \mathrm{a}$ & $36,0 \pm 4,2 \mathrm{a}$ & $135,7 \pm 11,0 \mathrm{a}$ & $4,2 \mathrm{a}$ \\
Caseína comercial & $332,4 \pm 31,4 \mathrm{a}$ & $33,3 \pm 3,1 \mathrm{a}$ & $123,4 \pm 9,5 \mathrm{a}$ & $4,3 \mathrm{a}$ \\
\hline Aprotéica & $101,0 \pm 22,5$ & $\sim 0$ & $(-14,9 \pm 1,3)$ & ND \\
\hline
\end{tabular}

$\mathrm{ND}=$ não determinado. Resultados são médias \pm desvios-padrão de 8 ratos/tratamento.

Letras diferentes (colunas) expressam resultados diferentes $(p<0,05)$. 
É interessante notar que, embora o consumo de dieta e de proteína e o ganho de peso no grupo tratado com AT tenham sido mais baixos (Tabela 4) em comparação com os demais tratamentos, exceto o LI, o NPR do AT não diferiu dos outros tratamentos $(p>0,05)$, indicando melhor utilização da proteína do autolisado.

O fato de se ter verificado uma diferença marcante no ganho de peso $(89,8 \mathrm{~g})$ e no índice NPR $(3,65)$ para a LI de cervejaria ${ }^{9}$, comparados com 25,4 g e 2,1 , respectivamente, para a LI de destilaria de álcool, sugere que esta levedura apresenta um aproveitamento bem inferior à de cervejaria, na forma de células íntegras (LI), provavelmente devido a um maior espessamento da parede celular, dificultando a digestão dessa estrutura da célula e o aproveitamento da proteína.
Essa afirmativa é corroborada pela maior digestibilidade da proteína $(83,0 \%)$ nas células íntegras (LI) de cervejaria ${ }^{9}$, contra apenas $68 \%$ nas células provenientes de destilaria de álcool, relatada neste trabalho. Tal diferença é, em grande parte, eliminada, submetendo-se as células íntegras da levedura de destilaria (LI) ao processo de autólise (AT) ou fazendo-se o isolamento da proteína, na forma de concentrado protéico.

A digestibilidade relatada ${ }^{9}$ para o AT de cervejaria foi de $86,5 \%$, enquanto para o AT obtido de células íntegras de destilaria foi de 76,6\% (Tabela 3). A digestibilidade do Ex variou de $91 \%$ (destilaria) a 95,4\% (cervejaria).

A comparação desses dados evidencia a importância do processamento, com vistas a

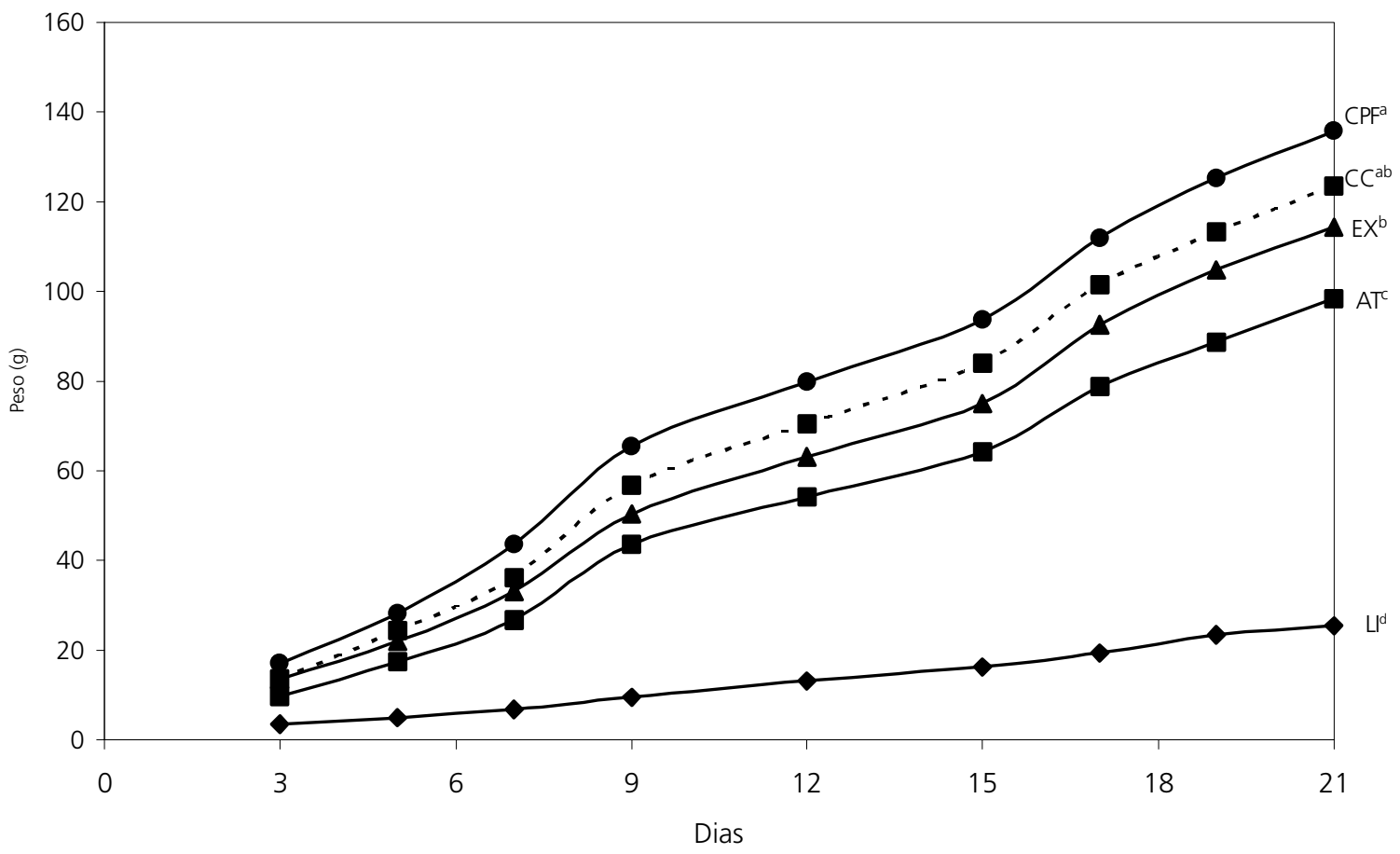

\begin{tabular}{ll|}
\hline - exedrato (EX) \\
- - - caseína (CC) (padrão)
\end{tabular}

Figura 2. Ganho de peso para ratos alimentados com dietas contendo caseína, levedura íntegra ou derivados de levedura como única fonte de proteína (10\%).

$a, b, c, d$ : Letras diferentes expressam diferenças estatísticas $(p<0,05)$. 
melhorar o valor nutritivo da levedura obtida como resíduo da fermentação alcoólica.

O consumo de dieta, o ganho de peso e o índice NPR não diferiram estatisticamente $(p>0,05)$, neste trabalho, entre Ex, CPF e caseína comercial (CC), evidenciando um elevado valor protéico para os derivados de levedura provenientes da fermentação alcoólica.

Analisando o ganho de peso acumulado nos diferentes tratamentos durante os 21 dias de alimentação dos ratos (Figura 2), maior crescimento foi observado no tratamento com CPF, seguido da CC; estas dietas não diferiram entre si do ponto de vista estatístico $(p>0,05)$. Seguiu-se o Ex, que não diferiu estatisticamente da CC, mas apresentou diferença estatística em relação ao CPF, enquanto o AT diferiu de todos os tratamentos, tendo sido superior apenas à $\mathrm{LI}$ e inferior estatisticamente aos demais.

Confrontando os resultados de crescimento de ratos tratados com $\mathrm{LI}$ e concentrado protéico extraído com perclorato de sódio, provenientes de levedura de cervejaria ${ }^{8}$, com os valores de ganho de peso dos ratos alimentados com as células íntegras (LI) e o concentrado protéico fosforilado deste trabalho (Figura 2), duas diferenças fundamentais tornam-se evidentes. $\mathrm{O}$ crescimento relatado com células íntegras de levedura de cervejaria foi muito superior ao encontrado neste estudo. Por outro lado, o crescimento relatado para ratos tratados com concentrado protéico, obtido com perclorato de sódio, foi bem inferior ao registrado no tratamento com LI de cervejaria ${ }^{8}$, divergindo dos resultados da presente pesquisa, em que o crescimento promovido pela LI foi muito baixo enquanto que o CPF promoveu o maior crescimento, sendo inclusive superior ao da caseína, embora sem diferença estatística.

\section{O N C L U S Ã O}

O conjunto dos dados apresentados e discutidos neste trabalho permite concluir: a) a levedura íntegra obtida como resíduo em destilaria de álcool apresenta baixo valor protéico, com baixa digestibilidade da proteína e baixa capacidade de promover crescimento em ratos; b) comparada com a levedura proveniente de cervejaria, a de destilaria apresenta menor digestibilidade e menor poder de promover crescimento (em ratos); c) a autólise e o fracionamento permitem a obtenção de derivados de levedura de destilaria (AT e Ex) com valor protéico bem superior à $\mathrm{LI}$ da qual originaram; esse processo permite eliminar, em boa parte, as diferenças entre produtos de levedura provenientes de cervejaria e os de destilaria de álcool; d) o concentrado protéico obtido por fosforilação da proteína com trimetafosfato de sódio (CPF) é muito superior ao obtido com perclorato de sódio; e) o valor protéico do CPF, bem como a sua capacidade de promover crescimento em ratos, igualou-se ao da caseína, adotada como proteína de referência.

\section{A GRADECIMENTOS}

Os autores agradecem à FAPESP pelo apoio financeiro e à COPERSUCAR pelo apoio financeiro e suporte técnico a este projeto.

\section{REFERÊ NCIAS}

1. Dziezak JD. Yeast and yeast derivatives: definitions, characteristics and processing. Food Technol 1987; 42(2):104-21.

2. Kinight S. Yeast protein enhances flavour and nutrition. Food Process 1986; 55(10):13-4.

3. Halasz A, Lásztity R. Use of yeast biomass in food production. Boca Raton: CRC Press; 1991. 312p.

4. Peixoto N. Processamento de produtos de biomassa de levedura para alimentação humana; potencial, mercado interno e externo. In: Anais do Workshop Produção de Biomassa de Levedura: em alimentação humana e animal; 1996; Campinas. Campinas: Ital; 1996. p.90-8. 
5. Furco AM. Produção de biomassa de levedura em destilarias de álcool. In: Anais do Workshop Produção de Biomassa de Levedura em Alimentação Animal e Humana; 1996: Campinas. Campinas: Ital; 1996. p.52-8.

6. Butolo JE. Uso de biomassa de levedura em alimentação animal: propriedades, custo relativo a outras formas de nutrientes. In: Anais do Workshop Produção de Biomassa de Levedura em Alimentação Animal e Humana; Agosto, 1996: Campinas. Campinas: Ital; 1996. p.70-89.

7. Sgarbieri VC, Alvim ID, Vilela ISD, Baldini VLS, Bragagnolo N. Produção piloto de derivados de levedura (Saccharomyces sp.) para uso como ingrediente na formulação de alimentos. Braz J Food Technol 1999; 2(1/2):119-25.

8. Caballero-Córdoba GM, Sgarbieri VC. Nutritional and toxicological evaluation of yeast (Saccharomyces cerevisiae) biomass and a yeast protein concentrate. J Sci Food Agric 2000; 80:341-51.

9. Vilela ESD, Sgarbieri VC, Alvim ID. Determinação do valor protéico de células íntegras, autolisado total e extrato de levedura (Saccharomyces sp.). Rev Nutr 2000; 13(3):185-92.

10. Vilela ESD, Sgarbieri VC, Alvim ID. Valor nutritivo da biomassa de células íntegras, do autolisado e do extrato de levedura originária de cervejaria. Rev Nutr 2000; 13(2):127-34.

11. Association of Official Agricultural Chemists. Official Methods of Analysis. 16th ed. Washington DC; 1998.

12. Bligh EG, DYER WJ. A rapid method of total lipid extraction and purification. Can J Biochem Physiol 1959; 37:911-7.

13. Asp N, Johansson C.G., Halmer H, Siljeström MA. A rapid enzymatic assay of insoluble and soluble dietary fiber. J Agric Food Chem 1983; 31(3): 476-82.
14. Herbert D, Phipps PJ, Stranger RE. Chemical analysis of microbial cells. In: Noris JR, Ribbors PW, editors. Methods of enzymology. London: Academic Press; 1971. v.5B.

15. Spies JR. Determination of tryptophan in proteins. Anal Chem 1967; 39(10):1412-15.

16. Reeves PG, Nielsen FH, Fahey Jr CC. AIN-93 purified diet for laboratory rodents: final report of the American Institute of Nutrition ad hoc Committee on the reformulation of the AIN-76a rodent diet. J Nutr 1993; 123(2):467-72.

17. Food and Agriculture Organization. Protein quality evaluation. Rome; 1989. 72p. (Report of a joint FAOMHO Expert Consultation, Food and Nutrition Paper, n.51).

18. Henley EC, Kuster JM. Protein quality evaluation by protein digestibility corrected amino acid scoring. Food Technol 1994; 48(4):74-7.

19. Pacheco MTB. Propriedades funcionais, nutricionais e toxicológicas de concentrados protéicos de levedura (Saccharomyces sp.) obtidos por diferentes processos de extração [tese]. Faculdade de Engenharia de Alimentos, UNICAMP; 1996. $158 p$.

20. Snider HE. Microbial sources of protein. Adv Food Res 1970; 18:85-91.

21. Galvez A, Ramírez MJ, Garcia-Garibay M. Chemical composition of a mixture of single cell protein obtained from Kluyveromyces fragilis and whey proteins. Arch Latinoam Nutr 1990; 40(2): 252-62.

22. Zinsly PF, Sgarbieri VC, Pereira Dias NFG, Jacobucci HB, Pacheco MTB, Baldini VLS. Produção piloto de concentrados de proteínas de leite bovino: composição e valor nutritivo. Braz J Food Technol 2001; 4:1-8.

Recebido para publicação em 7 de março de 2002 e aceito em 24 de março de 2003. 